\title{
bougainville women's role in conflict resolution in the bougainville peace process
}

\author{
Ruth Saovana-Spriggs \\ a scholar at the Australian National University, \\ Canberra, bases her analysis of conflict resolution \\ and restorative justice in Papua New Guinea on her \\ experiences as a participant and observer of tradition \\ and change in her homeland, Bougainville.
}

THE THEME of the conference for which this chapter was prepared was 'conflict management and restorative justice'. It entailed discussion of alternative approaches to the retributive justice system but ones that could be integrated into the overall legal system. Restorative justice is sometimes said to be rooted in the traditions of small-scale indigenous societies, such as in the Pacific Islands. It is wholesome, inclusive of people (including both the victims and the offenders), allows a sense of communal responsibility and participation in the process of dealing with law and order problems. It is unlike the formal institutionalised court systems, which are isolated and foreign to the majority of indigenous people. One of the underlying goals of this approach is to restore power and confidence to individuals and communities in correcting wrongs, restoring justice and building a more cohesive society.

This chapter covers two more issues that I did not have time to include at the conference: one being the problem of 'perception and belief' in restorative justice; the other being the difficulties encountered by the traditional-cultural restorative justice system in accommodating new changes and developments in contemporary Bougainville. I raise these issues simply to 
illustrate some of the difficulties and problems that restorative justice may encounter, particularly when traditional/cultural practices are applied. I will be touching on the following themes:

- $\quad$ the current situation in Bougainville in the year 2000;

- difficulties and problems in restorative justice from the cultural context;

- $\quad$ conflicting views or perceptions from the human rights point of view;

- $\quad$ the role of women in peacemaking in the peace process in Bougainville;

- $\quad$ why the traditional peace process has worked in the past and continues to work.

I am deliberately using the phrase 'peacemaking'. While it is important to restore justice, it is equally important to make peace. I think of Australia as a highly tolerant country. That is true in many ways. The word 'tolerance', however, can imply that negative feelings, such as aggression, remain, albeit in repressed or dormant form. One person can tolerate another but not necessarily be a friend or be at peace with them. Peace is needed for restorative justice to work. Once justice is restored, healing follows and this needs to take place in a peaceful climate.

\section{Some background to the current situation in Bougainville in the year 2000}

Bougainville is presently quiet and, I hope, not superficially so. In 1991 the Bougainville Interim Government (BIG) defected from the North Solomons Provincial Government and became the pro-Independence body. The Bougainville Transitional Government (BTG) was established within Papua New Guinea's constitutional requirements in 1996. Subsequently, a UN observers' mission, composed of international representatives, a Peace Monitoring Group comprising Australian, New Zealand, Fiji and Vanuatu soldiers, together with representatives of the government of Papua New Guinea, in conjunction with the Bougainville Interim Government and the warring factions, brought about a ceasefire 
agreement on 30 April 1998. The ceasefire agreement is now running successfully into its third year.

There are two interim political arrangements operating at present. Let me briefly go back in time. In May 1998 the Bougainville Constituent Assembly (BCA) was formed. The BCA embraced representatives from all parties, the churches and women's groups on the island. Owing to sporadic fighting in different parts of the island, it was formed on the basis of a combination of selection, nominations and appointments. This was the first tangible manifestation of Bougainville unity. This union set the social-political climate that allowed for a democratic, Bougainville-wide election a year later. The people elected a new body called the Bougainville Reconciliation Government in May 1999. It was later renamed the Bougainville People's Congress (BPC), symbolic of their aspiration for an independent homeland. Mr Joseph Kabui, the former North Solomons Premier (1986-1988) was elected unopposed by congressional members as the President. Two vice-presidents were elected: James Tanis from the south-central region and Thomas Anis from the north and the surrounding islands. It was necessary and important to have two vice-presidents. Having the north/islands and south/central vice-presidential positions was seen as a way of forging and strengthening the otherwise fragile unity of the Bougainville people.

Meanwhile, John Momis, who had been residing in Port Moresby throughout the crisis as the regional Member for Bougainville in the PNG Parliament, took the BPC to court, alleging that it was unconstitutional and therefore illegitimate. In late 1999 the Supreme Court of Papua New Guinea handed down its decision. The court declared that the formation of the Bougainville Peoples' Congress was illegal as it was formed outside PNG's constitutional requirements. Among the other consequences of this decision was the resumption of provincial government in Bougainville under the new PNG legislative reforms. This meant that John Momis automatically became the Governor of Bougainville. The status of governor gave him the power to select and appoint members to his government. 
Meanwhile, the BPC leadership and its members politely objected to his presiding over them. Instead they opted to step aside and let Momis and his interim Government run the show. To maintain continuity in the peace process, a consultative mechanism was set up whereby representatives from both sides would continue to meet and maintain communication and negotiations with the Government of Papua New Guinea.

Throughout the years of political conflict, the peace process continued. However, well before major international intervention, people at village level had already begun the peace process among themselves as early as 1990. Friends and foes were coming together in small numbers in different parts of the island. Members of warring factions were surrendering on their own accord, while others were persuaded to do so by the women, chiefs and churches. This development necessitated the formation of a Bougainville Reconciliation Government, an all-encompassing political body, as described earlier.

\section{Potential difficulties and conflicts in traditional restorative justice}

The aim in this section is to identify potential difficulties with conflict resolution and restorative justice in the traditional and modern settings of Bougainville. There is a need for careful investigation of approaches to conflict resolution in the traditional context. There is also the challenge of integrating traditional methods with those of the modern western legal system. What are the conditions that will allow both systems to work harmoniously in contemporary Bougainville and in Papua New Guinea?

\section{Example 1}

The 'haves' and the 'have nots' in urban areas

This example shows the difficulties a person might have in understanding legal or constitutional notions of justice, including restorative justice, as opposed to moral or customary perceptions of 'right 'and 'wrong' pertaining in their own home 
community. An individual in a squatter settlement in any major town or city may occasionally be driven by circumstance to theft. He might be just a decent fellow who does not have the means to bring an evening meal to his family. In the bewildering and culturally diverse urban environment, where many different traditions and values come together, this individual will naturally seek to legitimate his actions according to his own values. It is his firm belief that what he did was right. So why condemn the act? While restorative justice claims to 'condemn the sin but not the sinner', wouldn't its application in these circumstances simply compound the larger social injustice facing this unfortunate individual? How does his minor misdemeanour measure up against the corruption among high office-holders in Port Moresby? Where does an advocate of restorative justice draw the line? The issue of different perceptions, values and beliefs can thus present difficulties for the development and application of restorative justice in such a diverse and divided environment.

\section{Example 2}

\section{From pockets of Bougainville}

The scenario: $X$ intentionally kills $Y$ on his ( $\left.X^{\prime} s\right)$ land. This causes a bitter conflict between $X$ and $Y^{\prime}$ s clan members. How is this conflict resolved? Firstly, the community carefully selects a jury from within the community or neighbouring villages. The members in the panel must have extensive (and verified) knowledge of $X$ and $Y$ and other clan members. The jury must be as impartial as possible. In most cases, the jury consists of male chiefs. In the absence of female chiefs, the views of women are sought and represented by the related chief. In addition, they must try to establish if there were suspicious circumstances that led to the killing.

Why is land important in this particular issue? Land is an essential part of the compensation package in parts of the island. The final settlement would therefore include a portion of land given to the victim and his or her clan. 
However, giving away large tracts of land is becoming a real problem in Bougainville. With the growth of population and the increasing demand of the modern cash economy, large tracts of land are required for cash crops. This traditional way of restoring justice will not be able to survive within the context of new developments and demands in the society. What is the alternative? Return to the criminal justice system and send the culprit to goal? Kill a relative from X's clan to settle the score or bribe someone to do the job on X's behalf? Personally, I do not support or advocate any of these options. The dilemma requires creative thinking and wisdom in the search for alternative options that would continue to maintain fundamental principles while adjusting and responding to new needs and circumstances.

The significance of customary valuables in the resolution of conflict is very important. I wish to quote what my uncle had to say about the importance of traditional currency in an interview in 1993:

Our money is sacred. Waitman's money, you earn it today, you spend it today, too. But our money is not like that. It may have no real value in modern life but is significant in settling disputes. Once the payment in traditional currency is made, the conflicts cannot be challenged. Once you pay compensation with it, it seals the deal and that deal cannot be contested. The settlement will be a constant reminder to individuals, members of clans and communities for many generations to come. It is also a constant reminder to all that the particular act or crime must never be repeated. With the Waitman's money, spending it leaves a vacuum that has to be filled, and so one is driven to steal again or to kill again in order to get the Waitman's money again. There is no boundary to it, no sacredness to it. Our traditional money is sacred and we must never lose its value and significance. ${ }^{1}$

This is a very powerful statement of the value and significance of traditional currency in my community in Bougainville. 
However, this example illustrates additional dilemmas. In particular, it draws attention to the corrosive impact of modern currency on the value and significance of traditional currency in today's environment. As elsewhere in the Pacific, the younger generations are growing up in a world that revolves around the use of modern currency in both urban and rural areas. Many among the younger generation appear to be losing their respect for traditional currency.

I hope that there will remain a role for my uncle's view of traditional money in Bougainville society. Indeed, there are signs that traditional currency has regained its importance in many places and, in particular, has played a significant role in reconciliation ceremonies arising from the recent conflict. The loss of many other customary practices must not be the price that is paid when modern currency and lifestyle are adopted.

There are also obvious limitations to the value of traditional money in today's world. Take the case where a young woman falls pregnant outside marriage. The young man responsible refuses to marry the expectant mother. Both live in the village, where they have no regular income. The baby has to be supported. Conflict may arise. How can it be resolved using traditional means? Traditional currency will not provide for 'modern' necessities. It will not pay for nappies and other things associated with the child's health and upbringing. It will not pay school fees. How can traditional currency be used in such circumstances? Where do the two worlds meet?

In summary, there is a need to find common ground between traditional and contemporary approaches to conflict resolution and, in doing so, one has to tread carefully. What works in Bougainville may not necessarily work in neighbouring New Ireland. Furthermore, there is the need to strengthen, promote and accord respect to traditional customary practices in view of the issues discussed here. All in all, it is an interesting, exciting challenge to reinvigorate traditional structures and processes. 


\section{My involvement in the peace process}

My involvement in the peace process has been as a member of a particular women's organisation and as a member of a technical team. The technical team consists of some well educated Bougainvilleans, with myself as the only women member. I still feel it is disgraceful that the men went quiet on me when I requested to have at least one more woman in the team. This is an advisory team involved in mapping out popular demands and aspirations for independence from PNG. Women have been actively involved in pursuing the progressive political path that led to the creation of the Bougainville People's Congress (BPC). In every meeting of the BPC, there have been six women's representatives. Now that the Momis camp exists alongside the BPC, women's representatives have also been appointed to it. While the balance of representation favours the men, women's voices are heard and respected in both camps.

Women play multiple roles as negotiators, mediators and peacemakers. They provide checks and balances to their menfolk. To create a sweet romantic view of women here would be misleading. A very few women became irritant hecklers and were divisive in some meetings. There were those whose main motivation appeared to be to benefit from the limelight, to be seen as 'mothers of the peace process'. They often felt threatened by younger, educated, and powerful women. For the majority, however, their primary objective was, and remains, the building of a sense of cohesiveness and peace in the community.

\section{Women's efforts in conflict resolution and restorative justice}

This is a huge enterprise and women have played, and continue to play, a major role in the peace process. There are numerous players in this process, including the international community (New Zealand, Australia, Fiji, Vanuatu, the UN and various NGOs), the Papua New Guinea government, and, of course, the people of Bougainville. The focus in the following discussion is on the role of women in conflict resolution or, as I prefer to call it, 'peacemaking' in Bougainville. 
The process of conflict resolution in Bougainville is not a simple matter of 'condemning the act' and 'integrating the actor back into the community'. How do you integrate or re-orient an individual with post-war related traumatic experiences? This includes young men who took up arms and killed civilians, sometimes their own relatives. They have viewed many of their fellow islanders, relatives and friends, as traitors and enemies. This is a very different situation to the normal criminal case, for example, someone that occasionally steals. These young men have been fighting for a cause that has entailed 'taking it to the extreme' - not only taking lives, but destroying properties and, indeed, the whole infrastructure of Bougainville. Papua New Guinea's security forces had a major share in the mass destruction and loss of lives. The general population have seen and witnessed horrendous killings of loved ones, friends and relatives. The physical, psychological and spiritual scars of the civil war include widespread feelings of anger, bitterness, sadness, hopelessness, and enmity towards one another. There is a need to find out what happened to relatives who have disappeared. How does one deal with conflicts of this magnitude? How does one re-orient, re-settle and re-build the fabric of an entire society that once experienced progress and prosperity but was then plunged suddenly into a prolonged civil war? By 2000 Bougainvilleans had experienced a ten-year period of civil war that affected their hearts and minds as well as their physical well-being.

\section{The women's role in the peace process}

In discussing women's involvement in the peace process, I need to establish the context in which women exist and operate. One important dimension is that of their various churches, while another is provided by their traditional cultures and customs. It makes no sense to separate these domains. With regard to their social and political activities and influence, most women attribute these to their faith in God from where their strength and confidence are drawn. I found it extremely satisfying to observe the churches becoming progressively more receptive to women 
and not just the men who control the formal institutions of governance. It is very important to appreciate the power women hold in traditional Bougainville societies. Men respect this and allow women to exercise their power within the cultural context.

Women's power in Bougainville culture is fundamental. It is critical to their work as peacemakers. Let me briefly provide an overview of women's status in Bougainville society. ${ }^{2}$

- Women's position of power has its origin in the land. The land here does not belong to the clan but to the lineage in which the females are the authority. Women's prerogative over land includes defining land boundaries for gardening purposes or for lease or purchase, if male relatives make such requests; giving permission to hunt, to harvest timber for commercial and personal use; and the exclusive right to veto decisions on land related matters. While the male relatives have rights to ownership, their rights are quite limited and are conditional on the female relatives' 'tok orait' (permission). Consultation as a standard mechanism in the system addresses conflicting views and opinions and disputes, should men raise their flags. Women, however, still have the upper hand as the right to veto is exclusively theirs.

- $\quad$ The conceptualisation and symbolic significance of land is objectified in the female body. The body of a woman reproduces life for the next generation. Continuity in things traditional is essential and therefore a woman's body is crucial. Of course, males are just as important in the system of procreation, but their rights are limited and conditional upon the 'tok orait' (permission).

- $\quad$ The young fighters' perception of the women's role is that of peacemakers, mediators and negotiators interchangeably. Their role is perceived as neutral in the sense that women are non-combatants who do not carry weapons. Women are also seen, significantly, as members of kin: mothers, sisters, wives and relatives. Such relationships make a huge difference: they touch and move the men. They literally move them to disarm. 
- Bougainville females keep each matrilineal (not clan) heirloom. In modern terms, they are the treasurers. Consultation with males applies in this case, if and when problems arise. With land and traditional currency in the hands of women, theirs is indeed a powerful position.

- $\quad$ Females have authority over names. They have the right and privilege to give names to newly born babies although male relatives may express their opinions. The process of naming, including the traditional practice of maintaining names, has its own set of social and political networks which are directly linked to landownership.

- Both senior women and men are accorded respect and recognition in the titles they inherit. Male and female heads inherit the title 'lord' as in a 'moon sunano' (literal translation - 'a woman lord' in the Teop language, north -east of Bougainville) and a 'sunano' (a lord - simply refers to males and the authority enshrined in the title.) The early missionaries adopted this title to refer to Jesus Christ, the Lord, when translating portions of the Bible into the Teop language. This does not, however, have any bearing on the divinity of Jesus Christ. My own interpretation is that the Australian administrators in the 1950s (kiaps in PNG Pidgin) introduced the 'bigman' title and concept to the matrilineal areas. The use of 'bigman' and the use of 'lord' in Biblical translation and everyday usage have gradually eroded the application of the title 'lord' to both genders though not completely, as it is still used in many places today. ${ }^{3}$

Against this brief background, I will discuss the role of women in conflict resolution and their attempts to end the civil war on the island.

\section{Example 1}

PNGDF use of women's position of power.

The Bougainville Women for Peace and Freedom (BWPF) is a Bougainville-wide organisation. Most of its membership is from the south-west-central area, with some followers in the northern 
part of the island. It was formally established in about 1996. Its broad aims and objectives range from humanitarian to political and economic concerns. Early in 1998 an informal session was held at which women's traditional position of power was used in conflict resolution exercises. Here is a simple example related to me by a woman from the mountains of Arawa-Kieta in central Bougainville.

The scene: Two men are at loggerheads over an issue.

They lose control. Emotions erupt, ending in a violent physical confrontation. Intervention is required. Let us say a woman intervenes in this case. What does she do? She simply has to stand right in between the two men. The woman's presence does the job. The fight immediately stops and the men disappear from the scene as quickly as they can.

In 1989 one of the PNGDF's intelligence officers, who is from the Southern Highlands Province, learnt of the influential position of women and quickly capitalised on it. He used it in one of his operations in the Kieta-Arawa-Panguna area in central Bougainville. This is the area where the conflict started and is the heartland of the Bougainville Revolutionary Army (BRA). The operation was codenamed 'Operation Kisim Dog'. The broad aim was to collect people from the jungle up in the mountains and transport them down to care centres in Arawa town. These were the people who had fled into the jungles in the mountains of Panguna when the civil war broke out. The ultimate objective was to remove civilians from the jungle so that the PNGDF could go in and wipe out the BRA. Earlier attempts had failed. The effectiveness of this particular exercise lay in convincing the women of their security in care centres. A group of people, somewhat reluctantly, agreed to co-operate. This is what Liria Yauka had to say about the women of Kieta-Arawa:

But one thing the rebels respected and wouldn't endanger was their families; especially their mothers, sisters and wives. This respect was part of the customs and traditions of the matrilineal Bougainvillean society. It was in their blood, and that was our insurance. ${ }^{4}$ 
With this, according to the informant, he used a couple of women for a number of strategic manoeuvres: (a) as shields to protect groups of people who were willing to be taken by helicopters to care centres; (b) as guarantee that the people were honest with Liria and with his men; and (c) as a signpost or landmark in a specified area cleared for the helicopters to land.

\section{Example 2}

A team of four women. Turning a small meeting into a big meeting

In early 1999, by chance, I met up with a team of four women from Buin in the south of the island. They had been selected by the Catholic Women's Organisation. Their mission was to negotiate a meeting between two local armed groups of men who were in conflict with each other and had each killed a member of the other group. This was a localised incident and was a spillover from the broader Bougainville conflict. A week before my meeting with them, the four women had made their second attempt to track down the group of men who were hiding in the mountainous terrain. The women had already secured a guarantee from the lowlands' group that they would meet with their rivals under strict conditions.

The women spent a couple of nights in an old run-down classroom up in the mountains. The same building was used as the meeting place for the two groups. Prior to their departure, the nearby hamlets were notified of their mission. The leaders and chiefs of these hamlets sent word to the men in the jungle, informing them of the women's mission. The women had to wait for the men's response. Once their agreement was secured, the women hiked up to the mountains. On the eve of the first meeting, three representatives from the men's camp appeared. It was not a pleasant meeting. There was some conciliatory talk but accusations against the lowlands' camp dominated the discussion. The second day also amounted to little. All the while those who met were being fed by the villagers. The women returned, one could say, empty-handed and downhearted. But to the women, that was not the end of the process. The mission had only just 
begun. The women's mediatory role took almost five months before there were some tentative agreements to further meetings.

I was back in Arawa, Central Bougainville, in July of the same year. At that time, there was a large gathering of all south-central BRA commanders and chiefs in Arawa discussing this particular incident. In addition to discussing the reconciliation ceremony between the two groups, the men also discussed how to prevent similar incidents in future. This particular meeting was the result of the tireless efforts of the four women and their church group. A big reconciliation ceremony was staged soon after.

\section{Example 3}

Large meeting: Bougainville women unite/1994/1998/1999

The year 1994 was, in my view, the most significant time in the history of the Bougainville conflict. The first ever Bougainville-wide peace talks were held in Arawa in Central Bougainville between the Government of Papua New Guinea, its Security Forces, the people of Bougainville and the Bougainville Revolutionary Army. The BRA and its leadership refused to attend the meeting although they sent their junior members. Women were also invited and hundreds of them turned up. Various journalists reported the meeting as a failure due to the lack of attendance of the BRA's leadership. Despite this perception, however, the women initiated a phase of unity - the coming together of all Bougainville people. This was an important turning point for all Bougainvilleans. While it may have appeared an abstract union to many, it, nevertheless, confirmed the need to pursue this unity among Bougainvilleans.

How did women help forge this unity? One of the very first things the women did was to get together and put aside their differences of views and opinions and their affiliation to different factions. By this stage, people had categorised themselves as pro-Independence, thus as BRA followers; or as pro-PNG, in alliance with the PNG security forces and the local militia; or, alternatively, as a neutral group who did not take sides. Once 
the women had established open communication and some degree of understanding, they organised daily activities that facilitated the 'coming together'. The institution perceived as most neutral under the circumstances was the church. The combined churches' daily act of worship became the grinding machine in the hearts and minds of all the participants, paving the way to unity. The 'coming together' had its rough spots. Nonetheless, the women carried on and the process took a turn for the better. Secondly, the women were given a hearing in the daily meetings. They used this opportunity strategically to remind the men of the hardships that had been endured by mothers, wives, children, youth and the old people. It may have pained the ears of the men but it ultimately achieved its desired end. The third strategy was to appeal to the BRA men and its leadership over the radio on a daily basis. The content of the appeal was calculated. The women pleaded for the BRA and its leadership to come down from the mountains and join the meeting. When that did not work, the women changed tactic and instead spoke of their willingness to send a group of women to talk with them, face-to-face, up in the mountains. With this new tactic, the women expressed their utmost desire for a return to peace and to unite as one Bougainville people, as they had been prior to the civil war.

The atmosphere was tense throughout the week and full of rumours and suspicions. A couple of nasty incidents occurred when members of the PNG Security Forces shot one or two BRA representatives. This action simply confirmed the BRA's suspicions. Mr. Joseph Kabui, the President of the Bougainville Interim Government, agreed strongly with the women but, in his view, the time was not right.

In retrospect, the women's plea and demands may have appeared unsuccessful. I think otherwise. The women's plea registered with the men and haunted them as the years went by. These initial efforts established the momentum for peace that eventually led to the 1998 Lincoln Agreement.

Moving on from these early talks in 1994, two major peace talks were held at Burnham Military Barracks in 1997 in 
New Zealand. They were sponsored by the New Zealand government. A small group of Bougainville women attended each meeting. In the following year, in January 1998, a larger group of women (about fifty) attended the Lincoln Meeting in Christchurch, another significant breakthrough in the peace process. Women's efforts had a major influence in persuading men to accept a coming together of all Bougainville people. Foes and friends put aside their differences and began to acknowledge one another. Political aspirations and the need for peace were reconciled. This state of affairs eventually led to the formation of the Bougainville Constituent Assembly in May 1998, and then to the formation of the Bougainville Reconciliation Government/Bougainville People's Congress, referred to above, in early 1999 . These interim arrangements involved representatives from all the warring factions and parties, as well as from church and women's groups. This was an historic moment for the women. Their position and views were presented in a statement:

... To survive, we looked within our culture our traditional society and ourselves. In almost all areas of Bougainville, women traditionally own the land. The land is sacred and protected by men on behalf of the women. The men as guardians share leadership with women, taking the responsibility in open debate to protect women from potential conflict; however, women have the power to veto decisions, and therefore are involved in the final consultative process.

The destruction of this balance of powers as held in Bougainville in traditional times occurred through westernization in the colonial period. It is a tragic fact that the ignorance of external powers exercised in Bougainville by default weakened the traditional balance that kept a peaceful and harmonious society. In the recent absence of formal western political structures, our people in social crisis have turned to traditional decision making methods in which women 
have been restored to their rightful place in decision making methods, to their rightful place in leadership. Women have built bridges between their own families, clans and displaced fellow Bougainvilleans by working for mutual survival, whether it be in the bush, in care centres, or wherever they have hosted strangers in their own communities. Without remuneration they have laboured beside their men to create basic services using whatever talent or means they had (at) hand.

Today, we pay tribute to all the brave women who are waiting in our home land for news of peace and a return to a just civil society, where the rule of the gun will be replaced through a secure process for a permanent ceasefire and demilitarisation as agreed (upon) in the Lincoln Agreement.

Our menfolk have rediscovered the value of women sharing in the decision making process and we attest here today to the liberating effect this has had upon our fellow women delegates. As mothers of the land, we take seriously our responsibility to rebuild peace in our hearts and create a peaceful environment that will improve the quality of all our lives. There is so much to be done, whether it be developing ways to relieve or improve the back-breaking menial tasks; or restoring our lives so that we can freely move around, return to our homes and enjoy the ability to speak freely of our human rights and needs; or [asserting] our goals for a political future where women must take their rightful place as leaders beside their men. We look forward to being included in the new Bougainville government structure so that our rediscovery of women's participation will continue to shape and build Bougainville's development and government.

We have been here at Lincoln to break down the mental blockade that prevails in our home land, 
where women still live in fear and are not yet able to discuss and debate openly our democratic form of government.

In our society, although men and women have distinctive roles, they are complementary. We women are co-partners with our men and as such we are daunted by the enormous task that lies before us to bring about a new Bougainville. In holding to the peace message that has spread abroad in Bougainville from Burnham, we, the Women's Delegation at Lincoln University Leaders' meeting affirm with all our sisters and fellow Bougainvilleans our determination to make this peace process work until we reach our common goal of freedom ... ${ }^{5}$

\section{Why did the peace process work in Bougainville?}

The following are some thoughts deduced from the women's efforts, though it is not an exhaustive list.

- All Bougainvillean men and women, warring factions, leaders of traditional and modern institutions, have taken responsibility for the civil war and its consequences, indicating a willingness and determination to deal with the civil war and its devastating consequences. The north and the south and the outlying islands could have simply walked away from the problem, leaving it to the Panguna-Kieta-Arawa people to restore. But instead, all Bougainvilleans chose to solve the conflict, initially through traditional means of conflict resolution.

- It was not simply the desire to live peacefully and to regain human dignity and respect for life that drove the people to act in the way they did. I believe at the heart it was, and is, a fundamental commitment to an independent Bougainville. I recall parts of Joseph Kabui's speech at the Buin leaders' summit held in August of 1998 where he said something to this effect: 'The first thing we must do is define our destiny. Next, we must find the ship in which we must begin the journey in 
order to reach our destination.' It was a metaphor depicting the overwhelming support for independence all Bougainvilleans put forward at that meeting. The question now is how we get there.

- Women's role in the peace process must never be underestimated nor forgotten. Women were the initial brokers in the process. Against all odds and often at gunpoint, women risked their lives to calm young fighters, to speak and negotiate peace with them. It is also widely claimed by women that they drew and continue to draw their strength from their traditional-cultural structures and also from their faith in God. All women in Bougainville who lived through the crisis will have accounts of God's provision of refuge and protection, of provision of good health, love and care, and of food when food was scarce. In chaos, members of communities or societies find strength that leads them to finding solutions to their problems, so there is always victory at the end.

\section{Endnotes}

1 The author has translated her interview with her uncle in the Teop language liberally into English

2 Savoana-Spriggs, Ruth 1997. 'The civil War in Bougainville. Can women make a difference?'

3 Pauline Onsa, who was very active in assisting the International Red Cross in bringing medicine to areas where heavy fighting continued in the early years of the civil war, briefly discusses this position of power which women hold on Buka Island. See Onsa 1995. 'How the Bougainville crisis affected women on Buka Island'

$4 \quad$ Liria, Aluambo Yauka, 1993. Bougainville Campaign Diary: p 159

5 Bougainville Women's Press Statement, 1998, read by Mrs Agnes Titus, Lincoln. Christchurch, New Zealand 